\title{
Pathogen Variation and Urea Influence Selection and Success of Streptomyces Mixtures in Biological Control
}

\author{
L. K. Otto-Hanson, Z. Grabau, C. Rosen, C. E. Salomon, and L. L. Kinkel
}

First, second, and fifth authors: Department of Plant Pathology, and third author: Department of Soil, Water, and Climate, University of Minnesota, St. Paul 55108; and fourth author: Center for Drug Design, University of Minnesota, Minneapolis 55455. Accepted for publication 21 September 2012.

\section{ABSTRACT}

Otto-Hanson, L. K., Grabau, Z., Rosen, C., Salomon, C. E., and Kinkel, L. L. 2013. Pathogen variation and urea influence selection and success of Streptomyces mixtures in biological control. Phytopathology 103:34-42.

Success in biological control of plant diseases remains inconsistent in the field. A collection of well-characterized Streptomyces antagonists $(n=$ 19 isolates) was tested for their capacities to inhibit pathogenic Streptomyces scabies ( $n=15$ isolates). There was significant variation among antagonists in ability to inhibit pathogen isolates and among pathogens in their susceptibility to inhibition. Only one antagonist could inhibit all pathogens, and antagonist-pathogen interactions were highly specific, highlighting the limitations of single-strain inoculum in biological control.
However, the collection of pathogens could be inhibited by several combinations of antagonists, suggesting the potential for successful antagonist mixtures. Urea generally increased effectiveness of antagonists at inhibiting pathogens in vitro (increased mean inhibition zones) but its specific effects varied among antagonist-pathogen combinations. In greenhouse trials, urea enhanced the effectiveness of antagonist mixtures relative to individual antagonists in controlling potato scab. Although antagonist mixtures were frequently antagonistic in the absence of urea, all $n=2$ and $n=3$ antagonist-isolate combinations were synergistic in the presence of urea. This work provides insights into the efficacy of single- versus multiplestrain inocula in biological control and on the potential for nutrients to influence mixture success.
In principle, biological control offers an attractive alternative to pesticides for managing many soilborne plant pathogens. However, biological control in field settings often yields unpredictable results $(14,46,66)$, and researchers struggle to enhance the efficacy and consistency of biological control. Unfortunately, field studies often provide limited information on the factors that contribute to lack of success. Among the correlates of effective biological control, successful survival and colonization of inoculated biocontrol organisms are perceived to be most important (18). Specifically, successful biological control generally relies upon effective establishment in soil or on plants of high densities of microbial strains that are efficient at inhibiting pathogens via antibiotic inhibition, mycoparasitism, nutrient competition, chitinase production, or induced resistance $(1,11,48)$. Because of the presumed significance of colonization to successful disease control, there has been substantial focus on factors that influence colonization of the target habitat by the biocontrol organism $(18,22,32,57,59)$. Efforts have focused on maximizing inoculum dose, characterizing the relationships between population density and biocontrol success, and use of nutrient amendments to enhance colonization $(4,6,17,25,26,31,51,58)$.

In some systems, nutrient inputs have been shown to have a major impact on biocontrol. For example, when applied in conjunction with a nitrogen source, Trichoderma harzianum can significantly reduce Fusarium pathogen populations in cereal residues by increasing displacement and mortality of Fusarium spp., though benefits are heavily influenced by the form of nitrogen used $(27,29,50,60,68)$. Nutrient inputs have also been used to enhance colonization and biocontrol success for foliar plant pathogens (17). Because of their significant effects on antagonist

Corresponding author: L. K. Otto-Hanson; E-mail address: hans3583@umn.edu

http://dx.doi.org/10.1094/PHYTO-06-12-0129-R

(c) 2013 The American Phytopathological Society growth and production of antibiotics and extracellular enzymes in vitro $(15,20,44)$, nutrient amendments are also hypothesized to influence the capacity of inoculants to antagonize pathogen populations in vivo. However, despite the fact that inputs of nitrogen, potassium, and phosphorus are routine in field production systems as a means for supporting plant growth, there has been limited systematic consideration of the effects of nutrient amendments on antagonist colonization, pathogen suppression, or biocontrol in field settings.

Another relatively unexplored and potentially significant source of variation in the success of biocontrol is variation in the susceptibility of pathogen populations to antagonist inhibition. Whereas most antagonist screening strategies consider one or perhaps a small number of pathogen isolates, pathogen populations in the field can be highly diverse with respect to virulence profiles, phylogeny, and nonpathogenic phenotypes $(45,47,49)$. This may result in a highly heterogeneous population with respect to pathogen-antagonist interactions, yet there is little information on either variation in pathogen populations or the effects of this variation on biocontrol success in field settings.

Combining multiple antagonists has been explored as one strategy for enhancing the success of inoculative biocontrol. Theoretically, there are several benefits to combining biological control agents. Use of multiple antagonists with complementary environmental or ecological optima may enhance antagonist colonization and reduce variability of disease control in the field. Use of antagonists having distinct mechanisms or profiles of pathogen suppression may also increase the likelihood of suppression of a diverse pathogen population (62). Unfortunately, biocontrol mixtures have not consistently enhanced disease control (61). In fact, a recent review of 465 experiments contrasting strain mixtures with single-strain inoculants from 36 published studies found that the majority of interactions among strain mixtures were antagonistic with respect to disease suppression (66). Researchers continue to struggle to identify strategies that may fundamentally improve the success of biocontrol. 
Streptomyces spp. are common soil bacteria and prolific producers of antibiotics used commonly in both agriculture and medicine (10). Members of this genus have been used widely in biological control of diverse soilborne fungi, bacteria, and nematodes $(3,5,12,13,41,69)$. Multiple Streptomyces products are available commercially, including Mycostop (Verder Oy, Finland) and Actinovate (Natural Industries, Incorporated, Houston, TX). Streptomyces spp. are well known for their antibiotic inhibition of pathogens, though some isolates are superb competitors and others can produce degradative enzymes or plant-growth-promoting hormones $(37,38,53)$. However, antagonist selection strategies have focused primarily on antibiotic inhibition of plant pathogens $(26,43,57,70)$.

Several researchers have explored the potential for biological control of potato scab using antibiotic-producing Streptomyces spp. $(5,21,33,35,40,51,52,63)$. Streptomyces isolates from a naturally occurring scab-suppressive soil have shown substantial promise in controlling scab but their effectiveness in field trials has been frustratingly unpredictable. In this work, we quantify variation in both antagonist inhibitory capacities and pathogen resistance among populations of antagonist and pathogen isolates; the effects of nitrogen (urea) on antagonist inhibition, pathogen resistance, and potato scab biocontrol; and the potential for multiple strain combinations to enhance potato scab biocontrol in the presence and absence of added nitrogen. In addition, to assess the risk of introducing antibiotic resistance genes into the environment via inoculation of antibiotic-producing antagonists, we characterized the resistance capacities of antagonist and pathogen populations to clinically significant antibiotics in vitro. This information provides insight into sources of variation in potato scab biocontrol as well as a platform for improving efficacy and predictability of scab biocontrol in the field.

\section{MATERIALS AND METHODS}

Antagonist and pathogen collections. Antagonist $(n=19)$ and pathogen $(n=15)$ isolates were selected from an existing collection of pathogenic and antagonistic Streptomyces spp. in our lab $(2,8,9,35,51,52,55,56,65)$ (Table 1). The 15 pathogens were previously characterized Streptomyces scabies isolates (28). Antagonist and pathogen isolates were selected to represent a broad range of local and global natural and agricultural soils. All antagonist isolates had shown in vitro inhibition of pathogenic $S$. scabies or fungal plant pathogens in prior work $(34,51,52,65)$. Spores of Streptomyces isolates in the collection are maintained in a $20 \%$ glycerol solution and stored at $-80^{\circ} \mathrm{C}$.
Preparation of spore suspensions. Plates containing oatmeal agar (OA) (36) were inoculated with $100 \mu \mathrm{l}$ of the stock spore suspension of each antagonist and pathogen isolate and incubated at $27^{\circ} \mathrm{C}$ for 7 to 10 days. Spores were collected from culture plates using a sterile cotton applicator and placed in a $20 \%$ glycerol solution. Spore suspensions were stored at $-4^{\circ} \mathrm{C}$.

Characterization of antagonist-pathogen interactions. All possible antagonist-pathogen combinations were evaluated to determine the inhibitory activity of each antagonist and the sensitivity to inhibition of each pathogen. For antagonist-pathogen inhibition assays, plates containing $15 \mathrm{ml}$ of starch casein agar (SCA) (30) were dotted with four antagonists per plate $(10 \mu \mathrm{l} /$ antagonist), and each antagonist-pathogen interaction was replicated twice. Plates were incubated at $27^{\circ} \mathrm{C}$ for 3 days. After incubation, plates were inverted over a watch glass containing $4 \mathrm{ml}$ of chloroform for $1 \mathrm{~h}$ to kill antagonist isolates. Residual chloroform was allowed to evaporate from exposed plates in the safety cabinet for $30 \mathrm{~min}$. Plates were subsequently overlaid with $15 \mathrm{ml}$ of $1 \%$ water agar. Once solidified, $100 \mu \mathrm{l}$ of a pathogen isolate was spread evenly over the agar surface and incubated at $27^{\circ} \mathrm{C}$ for 3 days. Two right-angle measurements were recorded for each inhibition zone for all antagonist-pathogen interactions.

Effects of urea on antagonist-pathogen interactions. The effect of urea $\left\{\left(\mathrm{NH}_{2}\right)_{2} \mathrm{CO}\right\}$ on antagonist-pathogen interactions was determined for all pairwise isolate combinations. The experimental set-up was as described above; however, the primary SCA nitrogen source $\left(\mathrm{KNO}_{3} ; 278 \mathrm{ppm} \mathrm{N}\right)$ was replaced with urea at three concentrations: 184 ppm N (low), 920 ppm N (moderate), and 4,600 ppm $\mathrm{N}$ (high). Though the $\mathrm{KNO}_{3}(772 \mathrm{ppm} \mathrm{K})$ media component was replaced, a potassium source $\left(\mathrm{K}_{2} \mathrm{HPO}_{4} ; 900 \mathrm{ppm}\right.$ $\mathrm{K})$ was still present for the urea-amended SCA media. Each pathogen-antagonist interaction was replicated twice at each of the three urea concentrations.

Antagonist and pathogen resistance to medically important antibiotics. Resistance of pathogen and antagonist isolates was determined using a disc-diffusion assay against seven clinically significant antibiotics. Antibiotics tested, with corresponding concentrations per disc, included streptomycin $(10 \mu \mathrm{g})$, chloramphenicol $(30 \mu \mathrm{g})$, erythromycin $(15 \mu \mathrm{g})$, vancomycin $(30 \mu \mathrm{g})$, rifampin $(10 \mu \mathrm{g})$, amoxicillin/clavulanic acid $(30 \mu \mathrm{g})$, and tetracycline $(30 \mu \mathrm{g})$ (BD BBL Sensi-Disc; Becton, Dickinson and Company, Sparks, MD). For each of two replicates, $100 \mu \mathrm{l}$ of each isolate was spread evenly onto plates containing $15 \mathrm{ml}$ of SCA. The antibiotic discs were immediately applied to the inoculated plates, four different antibiotic discs per plate. Plates were incubated at $27^{\circ} \mathrm{C}$ for 3 days. Two right-angle measurements were

TABLE 1. Antagonist isolates, origin, habitat, GenBank accession number, and relevant references, when available

\begin{tabular}{|c|c|c|c|c|}
\hline Antagonist & Origin & Habitat & GenBank accession number ${ }^{\mathrm{a}}$ & References \\
\hline $2-12$ & Minnesota & Agricultural & AY277375.1 & 8,55 \\
\hline $4-16$ & Minnesota & Agricultural & AY277377.1 & 8,55 \\
\hline 15 & Minnesota & Agricultural & Not available & $35,52,65$ \\
\hline 93 & Minnesota & Agricultural & AY277380.1 & $8,35,51,52,56,65$ \\
\hline $1231-1$ & Minnesota & Prairie & AY465270.1 & 9 \\
\hline $1231-5$ & Minnesota & Prairie & AY465273.1 & 9 \\
\hline $1231-6$ & Minnesota & Prairie & AY465274.1 & 9 \\
\hline 5111-1 & Minnesota & Prairie & $(A Y 465312.1)$ & $\ldots$ \\
\hline $807-2 \mathrm{NZ}$ & New Zealand & Forest & Not available & $\ldots$ \\
\hline $840 \mathrm{NZ}$ & New Zealand & Forest & Not available & $\ldots$ \\
\hline $7 \mathrm{E} 101.7$ & Antarctica & Tundra & Not available & $\ldots$ \\
\hline CEV 2-12 & Europe & Forest & (FR692087.1) & $\ldots$ \\
\hline GS 93-23 & Minnesota & Agricultural & Not available & 65 \\
\hline Mont 3-17 & Europe & Forest & $(E F 516089.1)$ & $\ldots$ \\
\hline Pan FS 17 & Panama & Forest & (EU413898.1) & $\ldots$ \\
\hline TLI 030 & Kansas & Prairie & EU699506.1 & 2 \\
\hline TLI 103 & Kansas & Prairie & EU699569.1 & 2 \\
\hline TLI 149 & Kansas & Prairie & EU699613.1 & 2 \\
\hline WZ 1-25 & Europe & Forest & $($ EF063466.1) & $\ldots$ \\
\hline
\end{tabular}

a Antagonist sequences not found in GenBank were matched with the most similar BLAST sequence (accession number noted in parentheses and italics). 
recorded for each antibiotic inhibition zone for all antagonistpathogen interactions.

Effects of urea on pathogen resistance to antibiotics. Because the effects of nitrogen on pathogen-antagonist interactions cannot distinguish effects of nitrogen on antibiotic production by the antagonist from potential effects on resistance by the pathogen, we evaluated the effects of urea on pathogen resistance to the seven clinical antibiotics. The experimental set-up was as previously described; however, the standard SCA nitrogen source $\left(\mathrm{KNO}_{3} ; 278 \mathrm{ppm} \mathrm{N}\right)$ was replaced with three doses of urea as described above.

For each of two replicates, $100 \mu \mathrm{l}$ of each isolate was evenly applied to plates containing $15 \mathrm{ml}$ of SCA containing each concentration of the urea nutrient amendments. BD BBL Sensi-Disc antibiotic discs were immediately applied to the inoculated plates, four different antibiotic discs per plate, as described above. Plates were incubated at $27^{\circ} \mathrm{C}$ for 3 days. Antibiotic inhibition zones were measured for each interaction as described previously.

Evaluation of single versus multi-strain antagonist inoculum for controlling potato scab in vivo and the impacts of urea on disease control. Among the isolates evaluated here, three domestic isolates were chosen for further study based upon mean inhibition zone sizes, proportion of pathogens inhibited, and complementarity among isolates. Based upon these criteria, isolates 2-12, 15, and TLI 103 were selected for further study.

Soil collection. In November 2009, soil (Hubbard loamy sand; sandy, mixed, frigid Typic Hapludoll) was collected from throughout a potato scab test plot at the University of Minnesota Sand Plain Research Farm in Becker, MN. The field site has a history of moderate to heavy potato scab infestation. A total volume of $\approx 1,280$ liters of soil was collected and stored outside overwinter in the shade at the University of Minnesota, St. Paul campus until thawed for experimental set-up in early spring (March 2010).

Inoculum preparation. Cultures of each of the three isolates were grown on $\mathrm{OA}$ for 10 to 14 days at $27^{\circ} \mathrm{C}$. Aluminum trays (turkey roasting pans) containing $4,000 \mathrm{~cm}^{2}$ of coarse vermiculite and 1 liter of oatmeal broth were covered with heavy aluminum foil and sterilized twice on two consecutive days at $121^{\circ} \mathrm{C}$ for $1 \mathrm{~h}$. Spore suspensions of each isolate were prepared from two plates which were swabbed with a sterile cotton applicator, and the resulting spores were added to $20 \mathrm{ml}$ of sterile deionized water. The resulting spore suspension $(10 \mathrm{ml})$ was injected to one end of the sterile vermiculite mixture through the sterile aluminum foil using a sterile syringe; the remaining $10 \mathrm{ml}$ was injected into the opposite end of the same tray. Inoculum trays were covered with a second layer of sterile aluminum foil and placed on the bench top to incubate for 9 weeks. Trays were shaken daily to encourage even bacterial growth throughout.

Experimental design. Eight different inoculum combinations were evaluated in the greenhouse experiment: each individual isolate $(n=3)$, each isolate in all possible pairwise combinations $(n=3)$, a three-strain mixture $(n=1)$, and a noninoculated control $(n=1)$. All treatments were evaluated with and without urea, and each inoculum strain-urea treatment combination was replicated 10 times.

Experimental set-up. Soil collected from the Becker field plots was added to a large soil cart and mixed thoroughly. Soil was inoculated to produce a total inoculum dose of $7.5 \times 10^{9}$ cells/pot for all treatments (e.g., for the double- and triple-isolate combinations, each isolate inoculum was calculated so the final cell count for the combination of treatments was $7.5 \times 10^{9}$ cells/pot). For each inoculum treatment, inoculum and soil were combined in an industrial mixer and added to the pot. A single potato seed piece ('Red Pontiac', a scab-susceptible variety) was planted into each 8 liters of soil in each pot. For urea treatments, $1.38 \mathrm{~g}$ of urea $(46-0-0)(\approx 110 \mathrm{lb}$. of nitrogen per acre, which is comparable with what producers would apply in a field setting at sidedress) was mixed into the top-soil mixture above the seed piece to simulate nitrogen application in field settings. No other nutrient amendments were added to test pots, though residual nutrients may have been available from previous applications at the Becker field site. Pots were incubated on a greenhouse bench for 16 weeks, and treatments were randomly distributed on the bench. Greenhouse conditions were 21 to $24^{\circ} \mathrm{C}$ optimal daytime and nighttime temperature and 16-h day length, with supplemental light on overcast or short days. Pots were only watered as needed. Seven weeks after planting, soil was sampled from a subset of pots and nitrate-N was determined for each sample $(n=4)$.

Disease evaluation. At 16 weeks, potato plants were harvested. All tubers from each pot were collected in brown paper bags and stored at $4{ }^{\circ} \mathrm{C}$. Fresh weights of total tubers per pot and tuber count per pot were recorded within $24 \mathrm{~h}$ of harvest. For each tuber, percent tuber area covered (23); number of type 3,4 , and 5 lesions ( $3=$ periderm broken, $4=$ pit, and $5=$ deep pit) (34); and individual tuber weights were recorded.

Characterizing the efficacy of combined biological control strains. The Bliss independence method was used to determine whether inoculum combinations were additive, synergistic, or antagonistic as compared with the single isolate inocula $(19,66)$. We evaluated each pairwise and triple-isolate combination in comparison with the corresponding individual inocula. The formula for calculating the expected value for a two-isolate combination was modified to evaluate the triple-strain inoculum as follows: $E_{123}=E_{1}+E_{2}+E_{3}-\left(E_{1} \times E_{2}\right)-\left(E_{1} \times E_{3}\right)-\left(E_{2} \times E_{3}\right)+\left(E_{1} \times E_{2} \times\right.$ $\left.\mathrm{E}_{3}\right)$, where $\mathrm{E}_{\mathrm{x}}=$ expected control efficacy and $\mathrm{O}_{\mathrm{x}}=$ observed control efficacy when $x=$ inoculated isolate or isolates).

If the observed effect $\left(\mathrm{O}_{\mathrm{x}}\right)$ was greater than the expected effect $\left(E_{x}\right)$, then the interactions between the two biological control strains are defined as synergistic (66). In contrast, if $\mathrm{O}_{\mathrm{x}}<\mathrm{E}_{\mathrm{x}}$, then interactions are concluded to be antagonistic. When calculating effects of the combined BCAs for percent disease cover, nontransformed data were used.

Data analyses. Analysis of variance was performed using SAS 9.2 (PROC GLM) (54). Linear regression analyses were performed using GraphPad Prism 5.03 (16). Percent disease data were arcsine square root transformed prior to analysis of variance and regression analysis.

\section{RESULTS}

Characterization of antagonist-pathogen interactions. Antagonists varied significantly in their capacities to inhibit $S$. scabies isolates (Fig. 1). There were significant differences among the 19 antagonist isolates in mean inhibition zone sizes $(P<0.0001, \mathrm{df}=$ $18, F=135.72)$ and substantial variability in the percentage of pathogens each antagonist could inhibit (Fig. 1). Perhaps more importantly, antagonist-pathogen interactions were highly specific with respect to zone size (antagonist-pathogen interaction term $P<0.0001$, df $=250, F=10.65)$. Though the best candidate isolates for biocontrol should kill a large percentage of isolates and induce large inhibition zone sizes, these variables were not significantly correlated among isolates $\left(r^{2}=0.1096 ; P=0.1662\right)$. However, isolate CEV 2-12 could inhibit all pathogens isolates tested and had the largest mean inhibition kill zones. Finally, all but two antagonist isolates (2-12 and 15) were unique with respect to their inhibitory phenotypes (Fig. 2), or the specific subset of pathogen isolates they were able to inhibit. This shows that antagonist isolates produce a diverse array of distinct inhibitory compounds that vary in their effects on pathogens. Importantly, only a single isolate could inhibit all pathogen isolates, illustrating the challenge of developing single-strain biological control.

Similarly, pathogens varied in their susceptibility to inhibition by different antagonists. On average, individual pathogen isolates were inhibited by at least $50 \%$ (10) of the antagonists (Fig. 3). Pathogen isolate 82 exhibited especially strong resistance to in- 
hibition, and was inhibited by only $21 \%$ (4) of antagonist isolates. All pathogens had a unique resistance phenotype (Fig. 4), suggesting a tremendous diversity of resistance capacities within indigenous $S$. scabies populations. The diversity of resistance

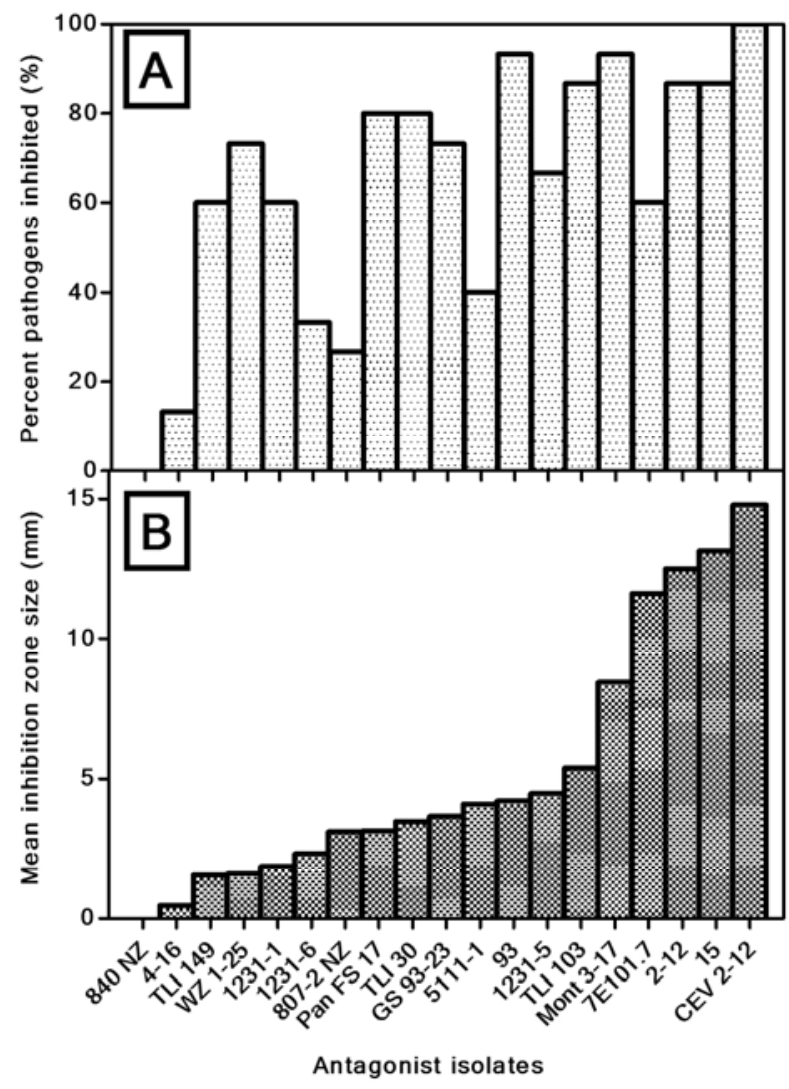

Fig. 1. Percentage of Streptomyces scabies pathogen isolates $(n=15)$ inhibited by antagonistic Streptomyces isolates (A) and corresponding mean inhibition zone sizes (B). Inhibition was determined by the presence and size of clear zones (lack of pathogen growth) in association with an antagonist isolate on starch casein agar. phenotypes suggests limited potential for any single antagonist to provide effective suppression of scab diseases.

Effects of urea on in vitro pathogen inhibition. In general, the intensity of inhibition of pathogens by antagonists increased with increasing urea. The effects of urea on pathogen inhibition varied among isolates; however, urea increased mean inhibition zone sizes for 112 of 200 antagonist-pathogen combinations (binomial; $P=0.0518$ ).

In contrast, the proportion of pathogens inhibited by antagonists declined with increasing urea. Antagonists clustered into distinct groups that exhibited steep declines in inhibition (eight isolates, 42\%), modest declines in inhibition (four isolates, $21 \%$ ), minimal declines in inhibition (five isolates, 26\%), or slight increases in inhibition (two isolates) in response to increasing urea (Fig. 5). Every antagonist isolate lost the capacity to inhibit at least one of the pathogen isolates with increased urea. Surprisingly, the best inhibitor (CEV 2-12) lost the capacity to inhibit 10 of the 15 pathogen isolates tested as urea increased (data not shown), which would be an important consideration in a biological control isolate selection process.

Resistance of antagonists and pathogens to clinically significant antibiotics. Pathogenic S. scabies isolates had substantial resistance to clinically significant antibiotics (Fig. 6). Pathogens were resistant, on average, to $42 \%$ of antibiotics tested, though resistance ranged from 29 to $82 \%$ of the antibiotics tested among pathogen isolates. All pathogens were resistant to erythromycin and rifampin. However, there was no resistance to vancomycin in any pathogen isolate.

Surprisingly, and in contrast, antagonist isolates had less resistance to clinically significant antibiotics than the pathogens. The antagonist isolates were resistant to a mean $8 \%$ of the antibiotics tested, with resistance to 0 to $28 \%$ of antibiotics. Only 8 of the 19 antagonist isolates tested had resistance to any of the medically important antibiotics tested, including rifampin, tetracycline, amoxicillin, or chloramphenicol. However, in most cases, antibiotic inhibition zone sizes were smaller for antagonists than for pathogens, suggesting that, if resistant, antagonists had greater capacities than pathogens to grow in the presence of the antibiotic.

Effects of urea on antibiotic inhibition of pathogens in vitro. To shed light on the specific effects of nitrogen on pathogen

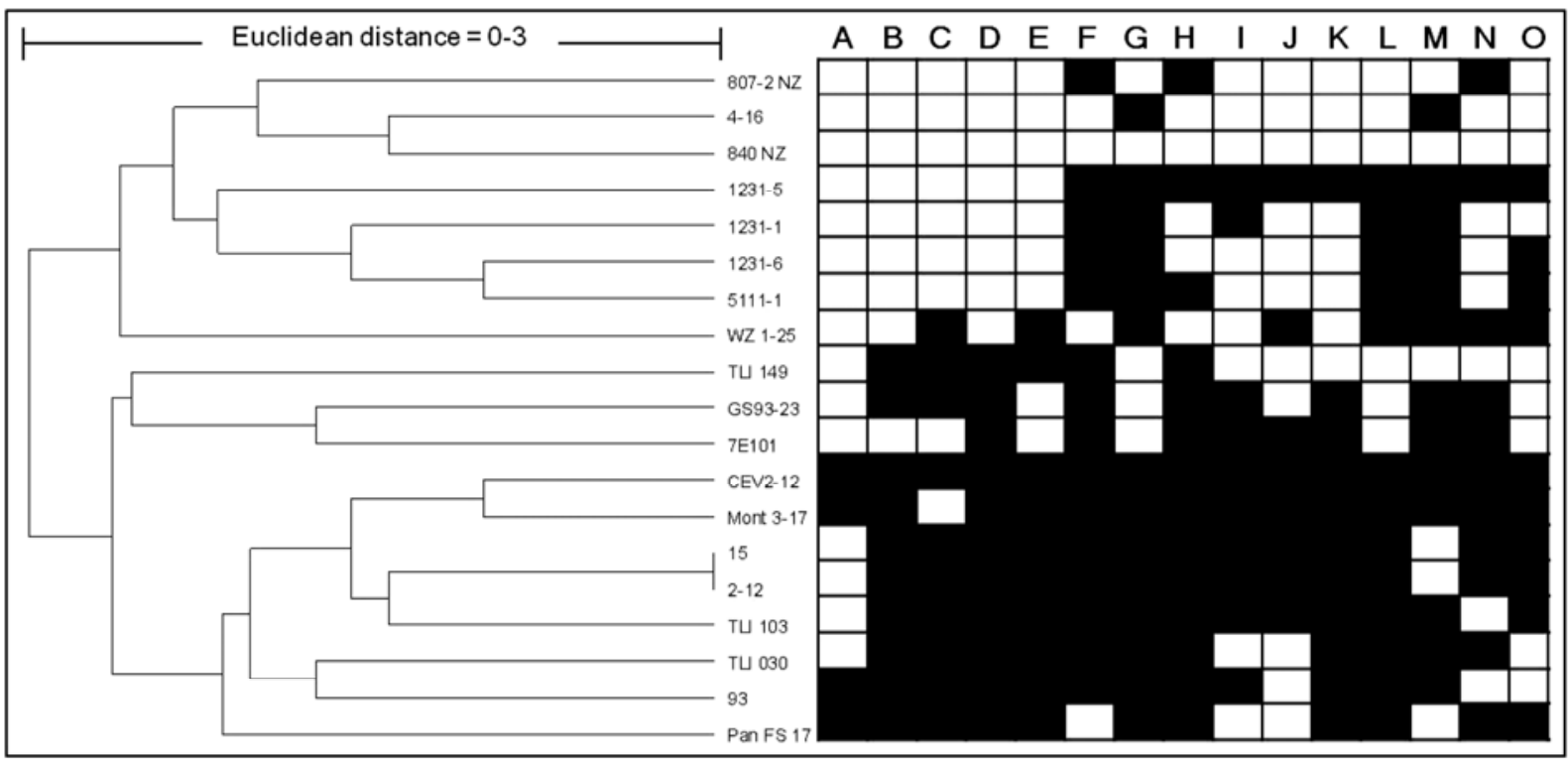

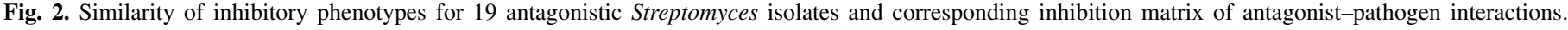

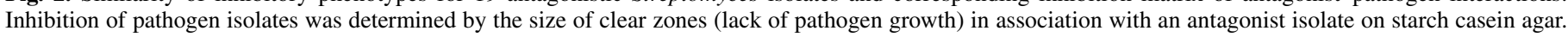

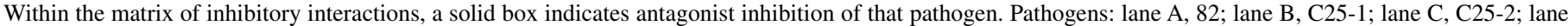

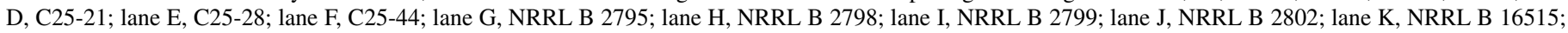
lane L, RL-39; lane M, WISN 01; lane N, NRRL B 2794; and lane O, NRRL B 2800. 
resistance as opposed to effects on antibiotic production by antagonists, we evaluated nitrogen influence on resistance of pathogens to antibiotics in vitro. Nitrogen demonstrated varied effects on resistance to clinically significant antibiotics among pathogen isolates. Results for nitrogen were confounded by the negative impacts of high nitrogen dose on pathogen growth; most pathogens did not grow on media containing the highest urea amendment. When increased from low to moderate doses, nitrogen had negative effects on pathogen resistance in $56 \%$ of cases; mean inhibition zone sizes increased with increased nitrogen. However, this effect was only significant for a single isolate (C25-2).

Evaluation of single versus multi-strain antagonist treatments and urea treatments on potato scab intensity. Recognizing the limitations of single-strain inoculum to provide comprehensive protection against diverse pathogen populations, we compared the control of potato scab using multiple-strain inocu-

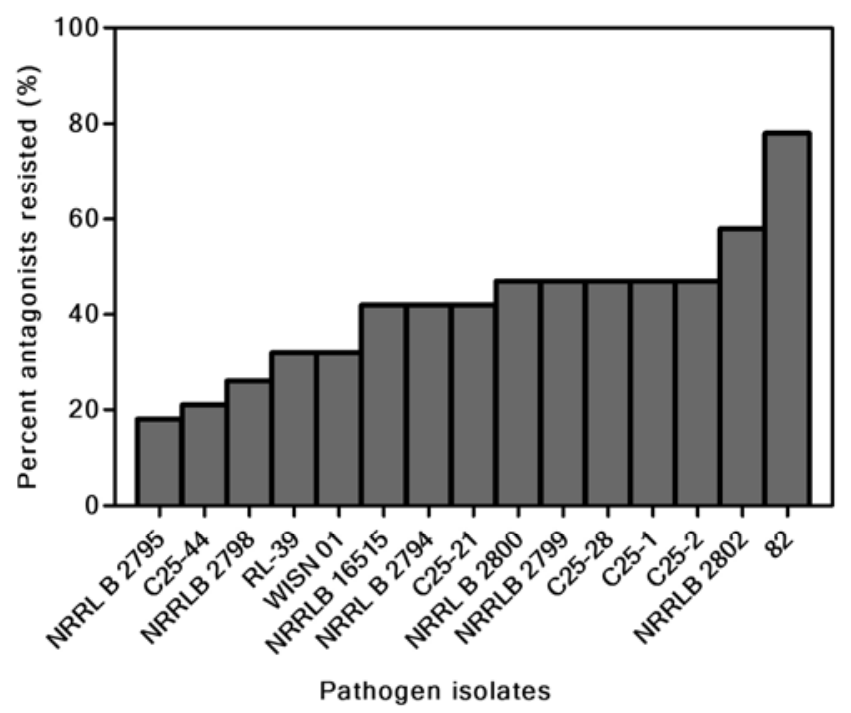

Fig. 3. Percentage of antagonists $(n=19)$ resisted by each of 15 pathogenic Streptomyces scabies isolates; resistance was assessed by the lack of a clear zone produced by the antagonist isolate in the presence of the pathogenic S. scabies. lum combinations with the traditional single-strain approach. Because nitrogen plays an essential role in production systems, we simultaneously evaluated effects of urea on potato scab biocontrol. A low incidence of potato scab in all treatments limited sensitivity to detection of antagonist effects on disease but, overall, the addition of urea produced a substantial reduction in disease for all inoculum treatments tested, including the control (Fig. 7).

Urea also had a substantial impact on scab biocontrol. In the presence of urea, there was a significant benefit of increasing numbers of isolates inoculated. Specifically, there was a significant negative correlation between the number of isolates inoculated and scab (mean number of lesions per tuber; $r^{2}=0.5654$, $P=0.05$ ) (Fig. 8) in the presence of urea. In contrast, in the absence of urea, the triple-strain inoculum had significantly higher percent disease cover and mean lesions per tuber than either the single or paired inoculum $(P=0.0090$, least significant difference $[\mathrm{LSD}]=0.0767$ and $P=0.0283, \mathrm{LSD}=3.1832$, respectively; $r^{2}=$ $0.0904, P=0.5122$ ). In the absence of urea, control was highly dependent on the specific isolate and there was little evidence for combined effects among isolates. Specifically, pots inoculated with isolate 2-12 alone or in pairwise combination with another

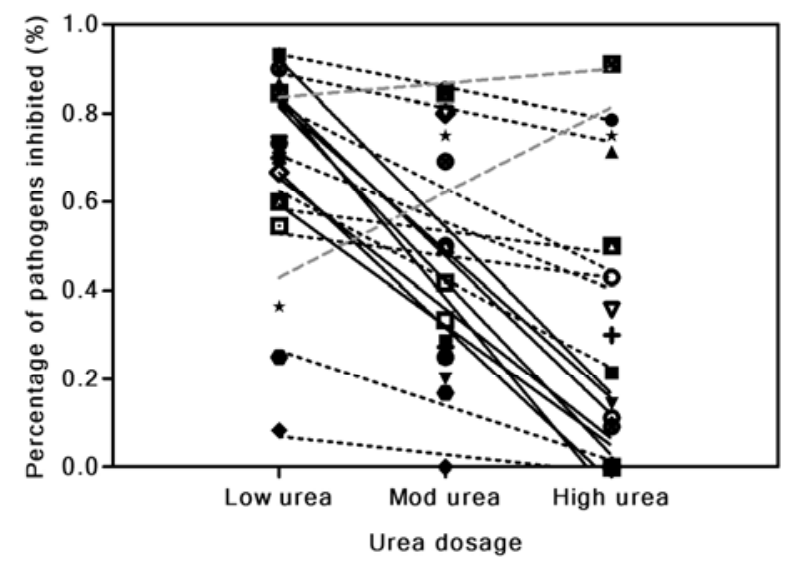

Fig. 5. Effects of low, moderate (Mod), and high urea on inhibition of pathogens by 19 antagonists as determined by the size of clear zones (lack of pathogen growth) in association with an antagonist isolate on starch casein agar.

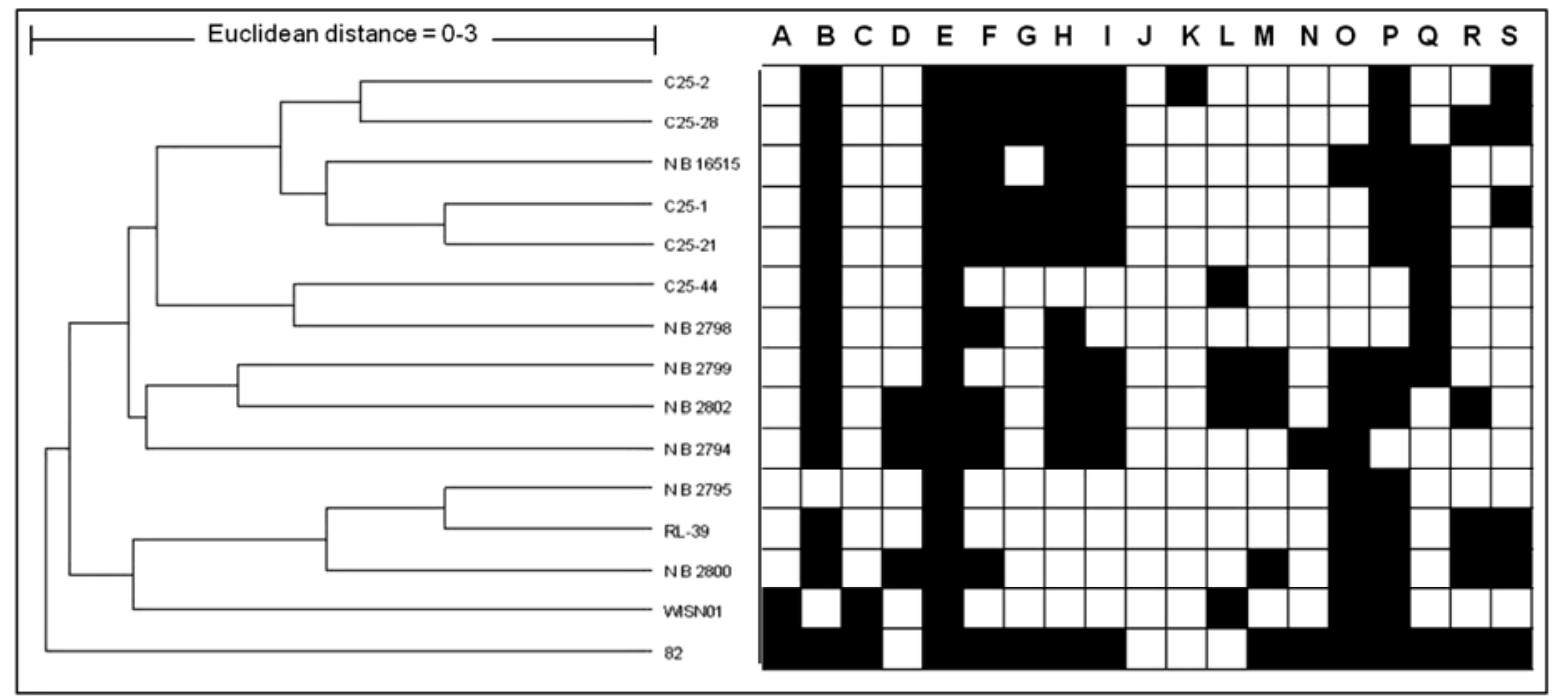

Fig. 4. Similarity of resistance phenotypes for 15 pathogenic Streptomyces scabies isolates and corresponding matrix of inhibitory interactions among all possible pathogen-antagonist combinations. Resistance of antagonist isolates was assessed by the lack of clear zones produced by antagonist isolates on starch casein agar. The dendrogram was created based on similarity of resistance phenotypes (matrix) measured in Euclidian distance. Within the matrix of inhibitory interactions, a solid box indicates pathogen resistance to antagonist inhibition. Antagonists: lane A, 2-12; lane B, 4-16; lane C, 15; lane D, 93; lane E, 840 NZ; lane F, 1231-1; lane G, 1231-5; lane H, 1231-6; lane I, 5111-1; lane J, CEV 2-12; lane K, MONT 3-17; lane L, PAN FS 17; lane M, TLI 30; lane N, TLI 103; lane O, TLI 149; lane P, 807 NZ; lane Q, WZ 1-25; lane R, GS93-23; and lane S, 7E101.7. 
isolate consistently performed best among treatments. In contrast, single isolate TLI 103 and isolates paired with TLI 103 (excluding 2-12/TLI 103) produced the worst control in the absence of urea. The relative ranking of treatments shifted notably in the presence and absence of urea; although the triple-isolate inoculant 2-12/TLI 103/15 and the double inoculant TLI 103/15 produced the worst control in the absence of urea, these treatments provided the best control in the presence of urea (Fig. 7). Not surprisingly, urea also significantly increased tuber yield (data not shown).

The Bliss independence analyses provided further insights into the effects of urea on isolate combinations and biocontrol. In the absence of urea, isolate combinations were predominantly antagonistic (Table 2; five of eight interactions). However, in the presence of urea, isolate combinations were consistently synergistic (Table 2; eight of eight interactions). This suggests that urea inputs fundamentally alter interactions among inoculated isolates and their consequent effects on scab disease.

\section{DISCUSSION}

Consistent success in biological control of plant diseases remains elusive in field settings. This reflects the complex challenges inherent in identifying antagonist strains capable of consistent suppression of often diverse pathogen populations, establishing antagonist populations within indigenous microbial communities, and maintaining antagonist efficacy in conjunction with agronomic practices. Although the prospects for disentangling the effects of these factors on biocontrol are daunting, systematic consideration of the variation in the pathogen population response to antagonists, specificity in pathogen-antagonist interactions, and effects of agronomic practices (nutrient inputs, plowing, and pesticides) on antagonist-pathogen interactions and biocontrol success is a critical prerequisite for improved biological control.

Among the collection of antagonists studied here, there was significant variation in the proportions of pathogens antagonists could inhibit and in the intensity of inhibition of individual pathogens. The diversity of inhibitory phenotypes and specificity of pathogen inhibition among antagonists suggests production of many distinct inhibitory compounds by different antagonists.

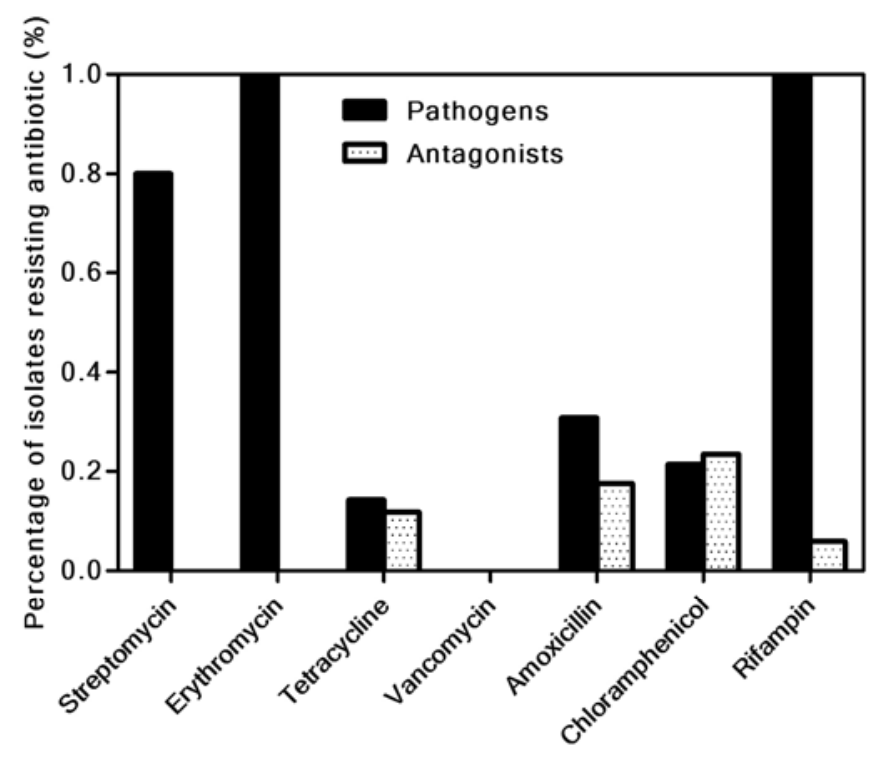

Antibiotics

Fig. 6. Resistance to clinically significant antibiotics by antagonistic $(n=19)$ and pathogenic $(n=15)$ Streptomyces sp. isolates. Resistance was defined as a lack of clear inhibition zones of Streptomyces sp. growth produced by the antibiotic disc on starch casein agar. Absence of a bar indicates that none $(0 \%)$ of the isolates tested were resistant to the antibiotic.
Simultaneously, the diversity among pathogens in resistance to antagonists and to clinically significant antibiotics is consistent with the presence of diverse resistance capacities within pathogen populations. In fact, no two pathogen isolates had the same resistance phenotype, illustrating tremendous variation in the potential for effective antagonist suppression within the pathogen population. Moreover, only one antagonist was capable of inhibiting all pathogen isolates, and every pathogen was resistant to at least one antagonist. This variation represents a significant challenge for consistent biological control. Importantly, despite the extensive diversity in pathogen resistance, no one pathogen was resistant to all antagonists, and every combination of pathogen isolates could be inhibited by an appropriate combination of antagonists. The pathogen isolates studied here were collected from diverse field locations from throughout the United States and, therefore, may represent a very diverse collection of pathogens. What is critical for effective biocontrol, however, is that an antagonist or combination of antagonists can suppress the majority of pathogen isolates within a particular field. However, the extent of diversity in resistance to antagonist inhibition within fields or across agricultural regions remains unknown. Such information will be crucial to identifying optimal antagonist strain combinations that may be both most likely to suppress local pathogen populations and least likely to select for substantial short-term resistance to suppression. Although these data emphasize differences in the capacity to inhibit (+ or -), which may be especially likely among Streptomyces populations (7), similar analyses considering the intensity of antagonism via antibiotic inhibition by Trichoderma spp. suggest a similar diversity and specificity of antagonistpathogen interactions among biological control systems (C. Perez, personal communication). Overall, these data highlight the po-

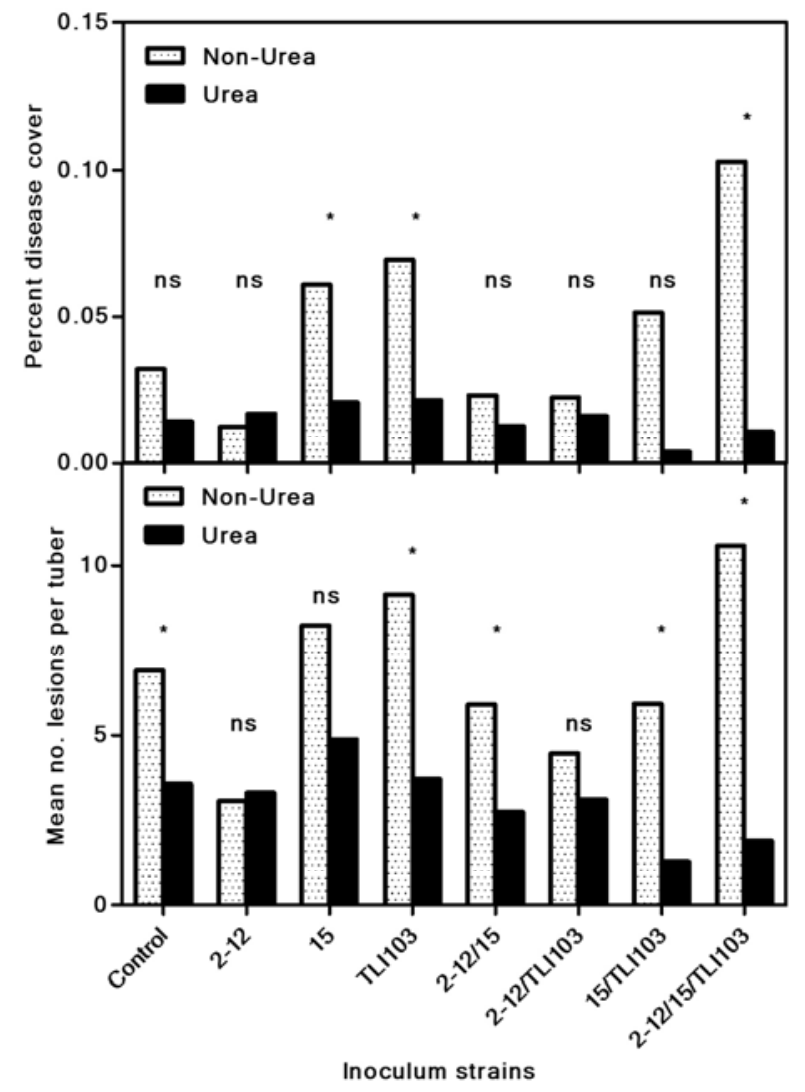

Fig. 7. Scab disease (percent cover and mean number of lesions per tuber) following inoculation with one, two, or three antagonistic Streptomyces isolates in the presence and absence of added urea $(*=$ significant difference identified between urea and non-urea treatments [ $t$ test, $P<0.05$ ], ns $=$ urea treatments were not significantly different than non-urea treatments). Disease was assessed 16 weeks after inoculation on all harvested tubers. 
tential significance of understanding the extent of variation in antagonist-pathogen interactions for diverse field populations.

Nitrogen, phosphorus, and potassium are virtually ubiquitous inputs in agricultural production systems, yet their effects on pathogen-antagonist interactions and biological control have received relatively little attention. Although the importance of nitrogen, carbon, phosphate, and other nutrients for microbial antibiotic production in pure culture has been well established $(24,42,50$, $64)$, this information is of little use in extrapolating to antagonistpathogen interactions. Recent work shows that addition of amino acids, nutrient supplements, and vitamins to the phyllosphere could enhance suppression of the foliar pathogen Botrytis cinerea on strawberry by Bacillus mycoides and Pichia guilermondii (17). McQuilken et al. (39) showed little effect of carbon or nitrogen manipulation (increase or decrease) on antifungal metabolite production by Coniothyrium minitans, though nutrition and $\mathrm{pH}$ together influenced inhibition of the pathogen Sclerotinia sclerotiorum by $C$. minitans in vitro (67). In the present work, increases in nitrogen availability (urea) generally increased the mean inhibition zone sizes among inhibitory antagonist-pathogen combinations, while the proportion of pathogens inhibited generally decreased for individual antagonists. Specifically, urea addition resulted in a complete loss of inhibitory capacity for all antagonists against at least one pathogen isolate, though loss of inhibition was specific to the antagonist-pathogen interaction. Thus, urea increased antagonist inhibitory capacity (zone size) but decreased the proportion of pathogens that could be inhibited. This shift in antagonistpathogen interactions in relation to nitrogen availability suggests the potential for urea to influence biocontrol field settings, though these effects are likely to be complex.

The effects of urea on antagonist-pathogen interactions may reflect the effects of nitrogen availability on antibiotic production by the antagonist, resistance by the pathogen, or both. We explored the direct effects of urea on pathogen resistance to anti- biotics using antibiotic discs. Effects of urea on antibiotic resistance varied widely among pathogens and among pathogenantibiotic combinations, with both significant increases and decreases in resistance to a given antibiotic with increased urea. Overall, these data suggest that standard agricultural inputs have the potential to significantly influence pathogen responses to antagonists, yet the responses may be highly variable among pathogen-antagonist combinations, and extrapolation from the lab to the field is likely to be difficult. However, these results emphasize the significance of understanding the specific effects of nutrients on different antagonist-pathogen interactions, as well as the diversity of pathogen populations within a field targeted for biological management.

Because only a single antagonist was able to inhibit all pathogens in the presence and absence of urea, and because antagonists varied in the effects of urea on their pathogen-inhibitory capacities, we selected three antagonists to study the potential benefits of single versus multiple strains in potato scab biocontrol. Because of United States Department of Agriculture Animal and Plant Health Inspection Service permit limitations, international isolates were not considered for greenhouse experiments. Antagonist isolates 2-12, 15, and TLI 103 were selected for study based upon their significant inhibitory capacities and the range of effects of urea on their capacities to inhibit pathogens. Thus, for example, although isolates $2-12$ and 15 had similar inhibitory patterns against the 15 pathogen isolates in the standard pairwise inhibition assay (Fig. 2), addition of urea had differing effects on the two isolates. Whereas addition of urea increased inhibition zone sizes for antagonist 2-12 against 57\% of the pathogens, isolate 15 had reduced inhibition zones sizes against $57 \%$ of the pathogens and completely lost its capacity to inhibit three pathogens. Antagonist TLI 103 had an inhibitory phenotype that was distinct from strains 2-12 and 15 and was highly sensitive to increases in urea. Whereas TLI 103 could inhibit $90 \%$ of pathogens at low urea, it couldn't

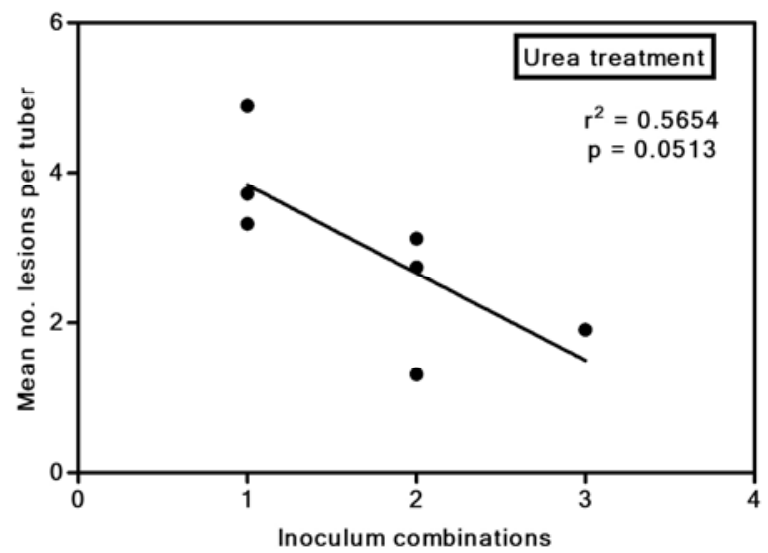

Fig. 8. Mean number of lesions per tuber for single-, paired-, and triple-strain inocula in the presence and absence of urea amendments.

TABLE 2. Bliss independence values characterizing double- and triple-strain combinations as antagonistic, synergistic, or additive ${ }^{\mathrm{a}}$

\begin{tabular}{|c|c|c|c|c|c|c|c|c|c|}
\hline Expected & $\begin{array}{c}\text { Disease } \\
\text { cover }(\%)\end{array}$ & Observed & $\begin{array}{c}\text { Disease } \\
\text { cover }(\%)\end{array}$ & Characteristic & Expected & $\begin{array}{c}\text { Number of } \\
\text { lesions }\end{array}$ & Observed & $\begin{array}{c}\text { Number of } \\
\text { lesions }\end{array}$ & Characteristic \\
\hline \multicolumn{10}{|l|}{ No urea } \\
\hline$E_{2-12 / 15}$ & 0.46 & $\mathrm{O}_{2-12 / 15}$ & 0.19 & Antagonistic & $E_{2-12 / 15}$ & 0.25 & $\mathrm{O}_{2-12 / 15}$ & 0.145 & Antagonistic \\
\hline $\mathrm{E}_{2-12 / \mathrm{TLI}}$ & 0.38 & $\mathrm{O}_{2-12 / \mathrm{TLI}}$ & 0.38 & Additive & $\mathrm{E}_{2-12 / \mathrm{TLI}}$ & 0.39 & $\mathrm{O}_{2-12 / \mathrm{TLI}}$ & 0.35 & Antagonistic \\
\hline $\mathrm{E}_{\mathrm{TLI} / 15}$ & -3.29 & $\mathrm{O}_{\mathrm{TLI} / 15}$ & -0.51 & Synergy & $\mathrm{E}_{\mathrm{TL} / 15}$ & -0.74 & $\mathrm{O}_{\mathrm{TLI} / 15}$ & 0.10 & Synergy \\
\hline $\mathrm{E}_{2-12 / 15 / \mathrm{TLI}}$ & 1.65 & $\mathrm{O}_{2-12 / 15 / \mathrm{TLI}}$ & -2.00 & Antagonistic & $\mathrm{E}_{2-12 / 15 / \mathrm{TLI}}$ & 0.24 & $\mathrm{O}_{2-12 / 15 / \text { TLI }}$ & -0.53 & Antagonistic \\
\hline \multicolumn{10}{|l|}{ Urea } \\
\hline$E_{2-12 / 15}$ & -0.61 & $\mathrm{O}_{2-12 / 15}$ & 0.14 & Synergy & $E_{2-12 / 15}$ & -0.26 & $\mathrm{O}_{2-12 / 15}$ & 0.23 & Synergy \\
\hline $\mathrm{E}_{2-12 / \mathrm{TLI}}$ & -0.77 & $\mathrm{O}_{2-12 / \mathrm{TLI}}$ & 0.0008 & Synergy & $\mathrm{E}_{2-12 / \mathrm{TLI}}$ & -0.042 & $\mathrm{O}_{2-12 / \mathrm{TLI}}$ & 0.13 & Synergy \\
\hline $\mathrm{E}_{\mathrm{TLI} / 15}$ & -1.19 & $\mathrm{O}_{\mathrm{TLI} / 15}$ & 0.82 & Synergy & $\mathrm{E}_{\mathrm{TLI} / 15}$ & -0.52 & $\mathrm{O}_{\mathrm{TLI} / 15}$ & 0.64 & Synergy \\
\hline $\mathrm{E}_{2-12 / 15 / \mathrm{TLI}}$ & -1.49 & $\mathrm{O}_{2-12 / 15 / \mathrm{TLI}}$ & 0.58 & Synergy & $\mathrm{E}_{2-12 / 15 / \mathrm{TLI}}$ & -0.42 & $\mathrm{O}_{2-12 / 15 / \mathrm{TLI}}$ & 0.16 & Synergy \\
\hline
\end{tabular}

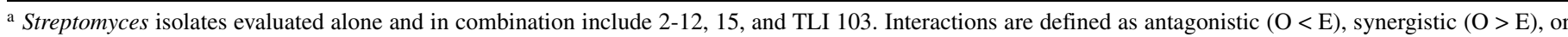
additive $(\mathrm{O}=\mathrm{E})$, where $\mathrm{E}_{\mathrm{x}}=$ expected control efficacy, $\mathrm{O}_{\mathrm{x}}=$ observed control efficacy, and $x=$ inoculated isolate or isolates. 
inhibit any pathogens under conditions of high urea. These three antagonists also differed in resistance to clinically significant antibiotics.

In the absence of urea addition, effective biocontrol was a function of the presence of antagonist 2-12. With no added urea, disease was lowest when isolate 2-12 was inoculated individually, increased slightly when 2-12 was paired with one other antagonist, and increased further when 2-12 was paired with both other antagonists, despite the fact that total antagonist inoculum density was constant among all treatments. These results are consistent with conclusions of $\mathrm{Xu}$ et al. (66), showing that disease suppression by paired $(n=2)$ inoculum strains is usually similar to that attained by the more efficacious strain, suggesting that one isolate in the pair is primarily responsible for disease suppression. In this work, strain combinations were consistently antagonistic in the absence of urea inputs (Table 2, Bliss independence values). In contrast, in the presence of urea, there was a significant benefit of increasing numbers of antagonists in controlling disease, and strain combinations were consistently synergistic. Thus, urea inputs enhanced the potential benefits of multiple versus singlestrain inoculum approaches for controlling potato scab. This may reflect direct effects of urea on antagonist colonization in soil, perhaps by reducing nitrogen limitation among Streptomyces isolates or by enhancing plant capacities for providing carbon to inoculated isolates. However, there are few data available on the extent to which nutrients influence the relative success of singleisolate versus multi-isolate biocontrol formulations. A recent meta-analysis by $\mathrm{Xu}$ et al. (66) considered 465 biocontrol studies contrasting single- versus multiple-strain inocula, and reported synergistic interactions in only $2 \%$ of all trials. Although antagonism is often assumed to be a function of inhibitory interactions among co-inoculated biocontrol isolates, the potential for nutrients to limit soil colonization and disease suppression by mixedstrain inocula deserves further study. This work highlights the significant potential effects of agronomic practices, especially nutrient inputs, on the outcomes of biocontrol and on the relative effectiveness of single- versus multiple-strain inocula in disease suppression.

Biocontrol research continues to struggle to attain consistent and effective disease suppression in field settings. This reflects the complex array of biological and edaphic factors likely to influence the success of antagonists in suppressing pathogens, including, for example, variation in indigenous pathogen populations, especially in their response to antagonists; the specificity of antagonist-pathogen interactions and antagonist-antagonist interactions in multiple-isolate inoculants; and the influences of nutrient inputs on pathogen-antagonist interactions. Significant advances in understanding and effectiveness of biological control in field settings are likely to require a sustained and systematic consideration of these factors. In addition to enhancing our understanding of the basic ecology of effective plant disease biocontrol, insight into these factors will provide a significant resource for predicting and prescribing optimal strategies for effective biocontrol.

\section{ACKNOWLEDGMENTS}

We thank the Healthy Foods, Healthy Lives Initiative and the Minnesota Agricultural Experiment Station (MIN-22-018) for their funding support; and K. Neshek and A. J. Lange for contributing significant technical support to our collective research effort.

\section{LITERATURE CITED}

1. Arras, G., and Arru, S. 1997. Mechanism of action of some microbial antagonists against fungal pathogens. Ann. Microbiol. Enzymol. 47:97120.

2. Bakker, M. G., Glover, J. D., Mai, J. G., and Kinkel, L. L. 2010. Plant community effects on the diversity and pathogen suppressive activity of soil streptomycetes. Appl. Soil Ecol. 46:35-42.
3. Bressan, W., and Figueiredo, J. E. F. 2007. Efficacy and dose-response relationship in biocontrol of Fusarium disease in maize by Streptomyces spp. Eur. J. Plant Pathol. 120:311-316.

4. Chatterton, S., and Punja, Z. K. 2010. Factors influencing colonization of cucumber roots by Clonostachys rosea $\mathrm{f}$. catenulata, a biological disease control agent. Biochem. Sci. Technol. 20:37-55.

5. Clermont, N., Lerat, S., and Beaulieu, C. 2011. Genome shuffling enhances biocontrol abilities of Streptomyces strains against two potato pathogens. J. Appl. Microbiol. 111:671-682.

6. Cunniffe, N. J., and Gilligan, C. A. 2011. A theoretical framework for biological control of soil-borne plant pathogens: identifying effective strategies. J. Theor. Biol. 278:32-43.

7. Davelos, A. L., Kinkel, L. L., and Samac, D. A. 2004. Spatial variation in frequency and intensity of antibiotic interactions among streptomycetes from prairie soil. Appl. Environ. Microbiol. 70:1051-1058.

8. Davelos, A. L., Xiao, K., Flor, J. M., and Kinkel, L. L. 2004. Genetic and phenotypic traits of streptomcetes used to characterize antibiotic activities of field-collected microbes. Can. J. Microbiol. 50:79-89.

9. Davelos, A. L., Xiao, K., Samac, D. A., Martin, A. P., and Kinkel, L. L. 2004. Spatial variation in Streptomyces genetic composition and diversity in a prairie soil. Microbiol. Ecol. 48:601-612.

10. Davies, J. 2007. Small molecules: The lexicon of biodiversity. J. Biotechnol. 129:3-5.

11. Elad, Y., and Freeman, S. 2002. Biological control of fungal plant pathogens. In: The Mycota XI: Agricultural Applications. Kempken, ed. Springer-Verlag, Berlin.

12. El-Tarabily, K. A., Nassar, A. H., Hardy, G. E. S. J., and Sivasithamparam, K. 2009. Plant growth promotion and biological control of Pythium aphanidermatum, a pathogen of cucumber, by endophytic actinomycetes. J. Appl. Microbiol. 106:13-26.

13. Esnard, J., Potter, T. L., and Zuckerman, B. M. 1995. Streptomyces costaricanus sp. nov., isolated from nematode-suppressive soil. Int. J. Syst. Bacteriol. 45:775-779.

14. Freeman, S., Minz, D., Kolesnik, I., Barbul, O., Zveibil, A., Maymon, M., Nitzani, Y., Kirshner, B., Rav-David, D., Bilu, A., Dag, A., Shafir, S., and Elad, Y. 2004. Trichoderma biocontrol of Colletotrichum acutatum and Botrytis cinerea and survival in strawberry. Eur. J. Plant Pathol. 110:361370.

15. Gao, L., and Liu, X. 2010. Nutritional requirements of mycelia growth and sporulation of several biocontrol fungi in submerged and on solid culture. Microbiology 79:612-619.

16. GraphPad Prism 5.03. GraphPad Software Inc., La Jolla, CA.

17. Guetsky, R., Elad, D., Shtienberg, D., and Dinoor, A. 2002. Improved biocontrol of Botrytis cinerea on detached strawberry leaves by adding nutritional supplements to a mixture of Pichia guilermondii and Bacillus mycoides. Biocontrol Sci. Technol. 12:625-630.

18. Guetsky, R., Shtienberg, D., Dinoor, A., and Elad, Y. 2002. Establishment, survival, and activity of the biocontrol agents Pichia guilermondii and Bacillus mycoides applied as a mixture on strawberry plants. Biocontrol Sci. Technol. 12:705-714.

19. Guetsky, R., Shteinberg, D., Elad, Y., Fischer, E., and Dinoor, A. 2002. Improving biological control by combining biocontrol agents each with several mechanisms of disease suppression. Phytopathology 92:976-985.

20. Heidari-Tajabadi, F., Ahmadzadeh, M., and Sharifi, R. 2011. Evaluation of biocontrol efficacy of Pseudomonas fluorescens UTPF61 in different nitrogen sources. J. Plant Pathol. 93:195-198.

21. Hiltunen, L. H., Ojanpera, T., Kortemaa, H., Richter, E., Lehtonen, M. J., and Valkonen, J. P. T. 2009. Interactions and biocontrol of pathogenic Streptomyces strains co-occurring in potato scab lesions. J. Appl. Microbiol. 106:199-212.

22. Hohmann, P., Jones, E. E., Hill, R. A., and Stewart, A. 2012. Ecological studies of the bio-inoculant Trichoderma hamatum LU592 in the root system of Pinus radiata. FEMS Microbiol. Ecol. 80:709-721.

23. James, W. C. 1971. An illustrated series of assessment keys for plant diseases, their preparation and usage. Can. Plant Dis. Surv. 51:39-65.

24. Jin, W., Kim, H. K., Kim, J. Y., Kang, S. G., Lee, S. H., and Lee, K. J. 2004. Cehpamycin C production is regulated by rel $A$ and $r s h$ genes in Streptomyces clavuligerus ATCC27064. J. Biotechnol. 114:81-87.

25. Johnson, K. B. 1994. Dose-response relationships and inundative biological control. Phytopathology 84:780-784.

26. Khare, E., and Arora, N. K. 2011. Dual activity of pyocyanin from Pseudomonas aeruginosa-against phytopathogen and signal molecule for biofilm development by rhizobia. Can. J. Microbiol. 57:708-713.

27. Khonga, K. B., and Sutton, J. C. 1991. Effects of acetic acid, propionic acid and urea on inoculum production by Gibberlla zeae in maize and wheat residues. Mycol. Res. 95:409-412.

28. Kinkel, L. L., Bowers, J. H., Shimizu, K., Neeno-Eckwall, E. C., and Schottel, J. L. 1998. Quantitative relationships among thaxtomin A production, potato scab severity, and fatty acid composition in Streptomyces. Can. J. Microbiol. 44:768-776. 
29. Kollmorgan, J. F. 1974. Some effects of urea and Streptomyces griseus (2-A24) on Fusarium avenaceum (Fr.) Sacc. Aust. J. Agric. Res. 25: 893-898.

30. Kuster, E., and Williams, S. T. 1964. Selection of media for isolation of streptomycetes. Nature 202:928-929.

31. Larkin, R. P., and Fravel, D. R. 1999. Mechanisms of action and doseresponse relationships governing biological control of Fusarium wilt of tomato by nonpathogenic Fusarium spp. Phytopathology 89:1152-1161.

32. Larsen, J., Graham, J. H., Cubero, J., and Ravnskov, S. 2012. Biocontrol traits of plant growth suppressive arbuscular mycorrhizal fungi against root rot in tomato caused by Pythium aphanidermatum. Eur. J. Plant Pathol. 133:361-369.

33. Lerat, S., Forest, M., Lauzier, A., Grondin, G., Lacelle, S., and Beaulieu, C. 2012. Potato suberin induces differentiation and secondary metabolism in the genus Streptomyces. Microbes Environ. 8:36-42.

34. Liu, D., Anderson, N. A., and Kinkel, L. L. 1995. Biological control of potato scab in the field with antagonistic Streptomyces scabies. Phytopathology 85:827-831.

35. Liu, D., Anderson, N. A., and Kinkel, L. L. 1996. Selection and characterization of strains of Streptomyces suppressive to the potato scab pathogen. Can. J. Microbiol. 42:487-502.

36. Lorang, J. M., Liu, D., Anderson, N. A., and Schottel, J. L. 1995. Identification of potato scab inducing and suppressive species of Streptomyces. Phytopathology 85:261-268.

37. Mahadevan, B., and Crawford, D. L. 1997. Properties of the chitinase of the antifungal biocontrol agent Streptomyces lydicus WYEC108. Enzyme Microbiol. Technol. 20:489-493.

38. Mahmoudi, E., Tabatabaei, B. E. S., and Venturi, V., 2011. Virulence attenuation of Pectobacterium carotovorum using N-Acyl-homoserine lactone degrading bacteria isolated from potato rhizosphere. Plant Pathol. J. 27:242-248.

39. McQuilken, M. P., Gemmell, J., and Whipps, J. M. 2002. Some nutritional factors affecting production of biomass and antifungal metabolites of Coniothyrium minitans. Biocontrol Sci. Technol. 12:443-454.

40. Meng, Q. X., Yin, J. F., Rosenzweig, N., Douches, D., and Hao, J. J. 2012. Culture-based assessment of microbial communities in soil suppressive to potato common scab. Plant Dis. 96:712-717.

41. Meschke, H., and Schrempf, H. 2010. Streptomyces lividans inhibits the proliferation of the fungus Verticillium dahlia on seeds and roots of Arabidopsis thaliana. Microbiol. Biotechnol. 3:428-443.

42. Mitra, A., Pramanik, A., Santra, S. C., Sen, P. K., and Mukherjee, J. 2011. Phylogeny, phenotypic and nutritional characteristics of estuarine soil actinomycetes having broad-spectrum antimicrobial activity derived from an ecologically guided biospecting programme. World J. Microbiol. Biotechnol. 27:1679-1688.

43. Neeno-Eckwall, E. C., Kinkel, L. L., and Schottel, J. L. 2001. Competition and antibiosis in the biological control of potato scab. Can. J. Microbiol. 47:332-340.

44. Nguyen, M. T., and Ranamukhaarachchi, S. L. 2010. Soil-borne antagonists for biological control of bacterial wilt disease caused by Ralstonia solanacearum in tomato and pepper. J. Plant Pathol. 92:395-406.

45. Otto-Hanson, L. K., Steadman, J. R., Higgins, R., and Eskridge, K. M. 2011. Variation in Sclerotinia sclerotiorum bean isolates from multisite resistance screening locations. Plant Dis. 95:1370-1377.

46. Paulitz, T. C., and Belanger, R. R. 2001. Biological control in greenhouse systems. Annu. Rev. Phytopathol. 39:103-133.

47. Pulawska, J., and Sobiczewski, P. 2012. Phenotypic and genetic diversity of Erwinia amylovora: the causal agent of fire blight. Trees Struct. Funct. 26:3-12.

48. Punja, Z. K., and Utkhede, R. S. 2003. Using fungi and yeasts to manage vegetable crop diseases. Trends Biotechnol. 21:400-407.

49. Rayatpanah, S., Nanagulyan, S. G., Alav, S. V., Razavi, M., and GhanbariMalidarreh, A. 2012. Pathogenic and genetic diversity among Iranian isolates of Macrophomina phaseolina. Chilean J. Agric. Res. 72:40-44.

50. Rigali, S., Titgemeyer, F., Barends, S., Mulder, S., Thomae, A. W., Hopwood, D. A., and van Wezel, G. P. 2008. Feast or famine: the global regulator DasR links nutrient stress to antibiotic production by Streptomyces. EMBO Rep. 9:670-675.

51. Ryan, A. D., and Kinkel L. L. 1997. Inoculum density and population dynamics of suppressive and pathogenic Streptomyces strains and their relationship to biological control of potato scab. Biol. Control 10:180186.

52. Ryan, A. D., Kinkel, L. L., and Schottel, J. L. 2004. Effect of pathogen isolate, potato cultivar, and antagonist strain on potato scab severity and biological control. Biocontrol Sci. Technol. 14:301-311.

53. Sadeghi, A., Karimi, E., Dahaji, P. A., Javid, M. G., Dalvand, Y., and Askari, H. 2012. Plant growth promoting activity of an auxin and siderophore producing isolate of Streptomyces under saline soil conditions. World J. Microbiol. Biotechnol. 28:1503-1509.

54. SAS 9.2. SAS Institute Inc., Cary, NC.

55. Schlatter, D. C., Fubuh, A., Xiao, K., Hernandez, D., Hobbie, S., and Kinkel, L. L. 2009. Resource amendments influence density and competitive phenotypes of Streptomyces in soil. Microbiol. Ecol. 57:413-420.

56. Schlatter, D. C., Samac, D. A., Tesfaye, M., and Kinkel, L. L. 2010. Rapid and specific method for evaluating Streptomyces competitive dynamics in complex soil communities. Appl. Environ. Microbiol. 76:2009-2012.

57. Shirzad, A., Fallahzadeh-Mamaghani, V., and Pazhouhandeh, M. 2012. Antagonistic potential of fluorescent pseudomonads and control of crown and root rot of cucumber caused by Phytophthora drechsleri. Plant Pathol. J. 28:1-9.

58. Shishido, M., Miwa, C., Usami, T., Amemiya, Y., and Johnson, K. B. 2005. Biological control efficacy of Fusarium wilt of tomato by nonpathogenic Fusarium oxysporum Fo-B2 in different environments. Phytopathology 95:1072-1080.

59. Singh, U. B., Sahu, A., Sahu, N., Singh, R. K., Renu, Prabha, R., Singh, D. R., Sarma, B. K., and Manna, M. C. 2012. Co-inoculation of Dactylaria brochopaga and Monacrosporium eudermatum affects disease dynamics and biochemical responses in tomato (Lycopersicon esculentum Mill.) to enhance bio-protection against Meloidogyne incognita. Crop Prot. 35:102-109.

60. Singh Lakhesar, D. P., Backhouse, D., and Kristiansen, P. 2010. Nutritional constraints on displacement of Fusarium pseudograminearum from cereal straw by antagonists. Biol. Control 55:241-247.

61. Stockwell, V. O., Johnson, K. B., Sugar, D., and Loper, J. E. 2010. Control of fire blight by Pseudomonas fluorescens A506 and Pantoea vagans C9-1 applied as single strains and mixed inocula. Phytopathology 100:1330-1339.

62. Stockwell, V. O., Johnson, K. B., Sugar, D., and Loper, J. E. 2011. Mechanistically compatible mixtures of bacterial antagonists improve biological control of fire blight of pear. Phytopathology 101:113-123.

63. Sturz, A. V., Peters, R. D., Carter, M. R., Sanderson, J. B., Matheson, B. G., and Christie, B. R. 2005. Variation in antibiosis ability, against potato pathogens, of bacterial communities recovered from the endo- and exoroots of potato crops produced under conventional versus minimum tillage systems. Can. J. Microbiol. 51:643-654.

64. Swiatek, M. A., Tenconi, E., Rigali, S., and van Wezel, G. P. 2012. Functional analysis of the $\mathrm{N}$-acetylglucosamine metabolic genes of Streptomyces coelicolor and role in control of development and antibiotic production. J. Bacteriol. 194:1136-1144.

65. Xiao, K., Kinkel, L. L., and Samac, D. A. 2002. Biological control of Phytophthora root rots on alfalfa and soybean with Streptomyces. Biol. Control 23:285-295.

66. Xu, X.-M., Jeffries, P., Pautasso, M., and Jeger, M. J. 2011. Combined use of biocontrol agents to manage plant diseases in theory and practice. Phytopathology 101:1024-1031.

67. Yang, R., Han, Y., Li, G., Jiang, D., and Huang, H.-C. 2008. Effects of ambient $\mathrm{pH}$ and nutritional factors on antifungal activity of the mycoparasite Coniothyrium minitans. Biol. Control 44:116-127.

68. Yi, C., Kaul, H. K., Kubler, E., and Aufhammer, W. 2002. Populations of Fusarium graminearum on crop residues as affected by incorporation depth, nitrogen and fungicide application. J. Plant Dis. Prot. 109:252-263.

69. Yuan, W. M., and Crawford, D. L. 1995. Characterization of Streptomyces lydicus WYE108 as potential biocontrol agent against fungal root and seed rots. Appl. Environ. Microbiol. 61:3119-3128.

70. Zhang, S. M., Wang, Y. X., Meng, L. Q., Li, J., Zhao, X. Y., Cao, X., Chen, X. L., Wang, A. X., and Li, J. F. 2012. Isolation and characterization of antifungal lipopeptides produced by the endophytic Bacillus amyloliquefaciens TF28. Afr. J. Microbiol. Res. 6:1747-1755. 